\title{
DIVIDEND POLICY OF INDONESIAN STATE-OWNED ENTERPRISES
}

\author{
Wahyuni Rusliyana Sari \\ Faculty of Economics and Business, Trisakti University, Jakarta \\ e-mail: wahyuni.rusliyana@trisakti.ac.id
}

\begin{abstract}
The purpose of this research is to identify the factors that influence the dividend policy. The model considered the impact of ownership structure, firm size, growth opportunities, financial leverage, profitability, business risk, age, previous year's dividends, and global crisis 2008 on dividend payout ratio. Sample in this research is state-owned enterprises listed in Indonesian Stock Exchange between the years from 2004-2013. With using purposive sampling, the total of the sample in this research is 8 state-owned companies. The methodology of this research was multiple regression linier. The result of this research find that firm size, previous year's dividends, and global crisis 2008 significant to dividend payout ratio. Ownership structure, growth opportunities, financial leverage, profitability, business risk, and age do not have significant to dividend payout ratio. This result indicates that the companies management has to consider firm size, previous year's dividends, and global crisis 2008 in dividend payout ratio.
\end{abstract}

Keywords: dividend payout ratio, ownership structure; size, growth, financial levegare

\begin{abstract}
Tujuan dari penelitian ini adalah untuk mengidentifikasi faktor-faktor yang mempengaruhi kebijakan dividen. Model ini mempertimbangkan struktur kepemilikan, ukuran perusahaan, peluang pertumbuhan, leverage keuangan, keuntungan, risiko bisnis, umur perusahaan, dividen tahun sebelumnya, dan krisis global 2008 terhadap rasio pembayaran dividen. Sampel dalam penelitian ini adalah perusahaan Badan Usaha Milik Negara (BUMN) yang terdaftar di Bursa Efek Indonesia antara tahun 2004-2013. Dengan menggunakan purposive sampling, total sampel dalam penelitian ini adalah 8 perusahaan BUMN. Metodologi dalam penelitian ini adalah regresi linier berganda. Hasil dari penelitian ini adalah ukuran perusahaan, dividend tahun sebelumnya, dan krisis global 2008 berpengaruh terhadap rasio pembayaran dividen. Struktur kepemilikan, peluang pertumbuhan, leverage keuangan, keuntungan, risiko bisnis, dan umur perusahaan tidak berpengaruh terhadap rasio pembayaran dividen. Hasil ini mengindikasikan manajemen perusahaan harus mempertimbangkan ukuran perusahaan, dividen tahun sebelumnya, dan krisis global 2008 memiliki pengaruh terhadap rasio pembayaran dividen.
\end{abstract}

Kata kunci: rasio pembayaran dividen, struktur kepemilikan, ukuran perusahaan, peluang pertumbuhan, leverage keuangan 


\section{INTRODUCTION}

The topic of dividend policy is one of the most important topics in modern corporate finance. If we discuss the dividend policy then a lot of factors that we can involve. But as the word Black (1976) "the harder we look at the dividend picture, the more it seems like a puzzle, with pieces that just don't fit together". Decades of dividend policy topics have become enigmatic, causing conflicts, hypothesis debates, and explanations.

Miller \& Modigliani (1961) stated that the dividend irrelevance theory, in a perfect world, the firm's values is determined solely by the earning power and risk of its assets (investmnet) and that the manner in which it splits its earnings stream between dividends and internally retained (and reinvested) funds does not affect this value. Therefore, Miller\& Modigliani (1961) argue, that can be a clientele effect the argument that different payout policies attract different types of investors but still do bot change the value of the firm.

Lintner (1962) the key argument in support of dividend relevance theory that there is a direct relationship between a firm's dividend policy and its market value. Fundamental to this proposition is their bird-in-the-hand argument, which suggest that investors see current dividends as less risky than future dividends or capital gains. One interpretation of this evidence is that is not the devidends that matter but rather the informational content of dividends with respect to future earnings, which causes owner to bid up or down the price of the firm's stock. Another argument in support of the idea that dividends can affect the value of the firm is the agency cost theory. The agency cost theory says that a firm that commits to paying dividends is reassuring shareholders that managers will not waste their money.

Dividend policy in developed and developing countries may be different.
Developed countries already have economic, political, legal, educational, and technological progress. While in developing countries are still not able to think like a developed country. Although both developing countries, not necessarily dividend policy theories will be the same results if applied in other developing countries.

Indonesia is one of the developing countries in Southeast Asia. Indonesia is a rich country seen from its nature, unfortunately its human resources are still not able to utilize its wealth, so there are still many foreign countries intervention to explore the wealth of Indonesia. Including to develop the nation's economic progress with investment.

Modern life requires us to think how to prepare for a better future, where the economic competition is getting tighter. What should we do to meet our daily needs, healthcare costs, education, protect our assets from inflationary pressure and achieve financial freedom in retirement. Investment is the answer.

An investment is a commitment of fund in the expectation of some positive rate of return (Bodie et al., 2014). Based on the above definition it can be concluded that the investment is to save some money in the hope of getting additional profit from the money we save.

Investments are categorized into two types: real assets and financial assets. Real assets are tangible assets, such as investment in land, gold, property, collectibles, and others. While the financial assets are assets that are intangible but in the form of ownership claims, such as deposits, mutual funds, bonds and shares. So there is a term time value of money where many people are competing to invest his money now rather than later on for sake avoid risk and gain profit (Gitman, 2015).

According to Satriani (2014) investment on deposit interest rate guarantee LPS the 
period 15 September 2014 to 14 January 2015 on denominated deposits Rupiah at 7.75\%.

While investing in Bonds of the Republic of Indonesia (ORI) there are:

Table 1. ORI 2006-2013:

\begin{tabular}{ccc}
\hline ORI & Year & Coupon (\%) \\
\hline 001 & 2006 & 12.50 \\
002 & 2007 & 9.28 \\
003 & 2007 & 9.40 \\
004 & 2008 & 9.50 \\
005 & 2008 & 11.45 \\
006 & 2009 & 9.35 \\
007 & 2010 & 7.95 \\
008 & 2011 & 7.30 \\
009 & 2012 & 6.25 \\
010 & 2013 & 8.50 \\
\hline
\end{tabular}

Source: Kontan, 29 September 2014

The following is the gold price $(\mathrm{Rp} / \mathrm{Kg})$ from 2005-2014:

Table 2. The gold price 2005-2014

\begin{tabular}{cc}
\hline Year & Price $(\mathbf{R p} / \mathbf{K g})$ \\
\hline 2005 & $159.019 .887,45$ \\
2006 & $182.639 .222,83$ \\
2007 & $253.730 .123,83$ \\
2008 & $305.278 .536,58$ \\
2009 & $344.923 .567,19$ \\
2010 & $402.915 .136,48$ \\
2011 & $471.804 .881,95$ \\
2012 & $513.660 .935,49$ \\
2013 & $471.477 .780,26$ \\
2014 & $470.822 .030,42$ \\
\hline
\end{tabular}

Source: www.goldprice.org

The following is the IHSG data from 20052014:

Table 3. IHSG 2005-2014

\begin{tabular}{cc}
\hline Year & IHSG (Rp) \\
\hline 2005 & $1.162,635$ \\
2006 & $1.805,523$ \\
2007 & $2.745,826$ \\
2008 & $1.355,408$ \\
2009 & $2.534,356$ \\
2010 & $3.703,512$ \\
2011 & $3.821,992$ \\
2012 & $4.316,687$ \\
2013 & $4.274,177$ \\
2014 & $5.226,947$ \\
\hline
\end{tabular}

Source: IDX Statistics Book 2006-2014
Of the four investments can be concluded that the investment in stocks provides the highest rate of return on average growth IHSG year 2005-2014 amounted to $25.26 \%$ when compared with investment in Gold year 2005-2014 which has an average price growth of $13.50 \%$, while the maximum coupon of Indonesian Republic Bonds (ORI) year 2006-2013 is $12.05 \%$ and Time Deposit only has interest rate of $7.75 \%$. Therefore this study focuses on stocks.

Indonesia is a small open economy country so the impact of the crisis global finance greatly affect the condition of the domestic economy. Wrong one impact of the global financial crisis is the slowdown in economic growth Indonesia in 2008. The growth of the Indonesian economy as a whole grew to $6.1 \%$ in 2008 or slightly lower than with year 2007 of $6.3 \%$. Three negative impacts of the 2008 global crisis for Indonesia, among others:

First, the performance of the declining balance of payments. The decline in purchasing power in the United States led to a decrease in import demand from Indonesia. Indonesia's exports also declined. This is what caused it Indonesia's balance of payments deficit (NPI).

Second, decrease in the Rupiah exchange rate. The rupiah weakened to $\mathrm{Rp}$ 11,711, - per USD in November 2008 which is a major depreciation.

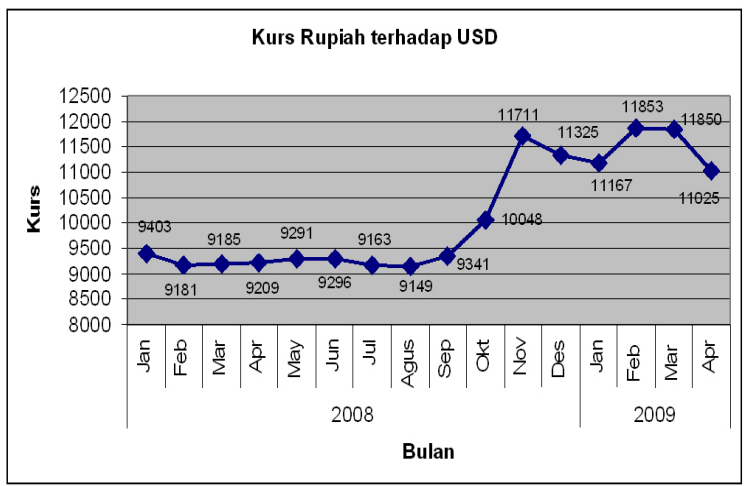

Figure 1. IDR Rate to USD 2008-2009

Source: www.bi.go.id 
Third, an increase in the rate of inflation. From the graph shows that there is high inflation pressure up to quarter III-2008 $12.14 \%$ ie until September 2008. This is triggered byrising world commodity prices, especially oil and food.

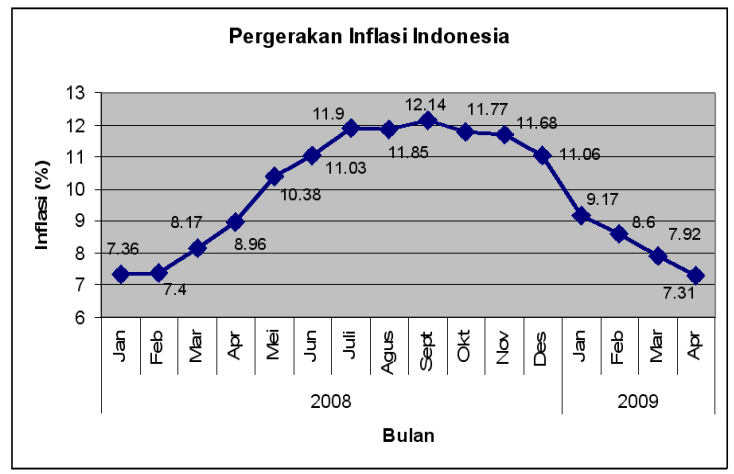

Figure 2. Inflation Data 2008-2009

Source: www.bi.go.id

The interest in researching stocks lies at the highest level of profit when compared to other investments, but it also lies in fluctuating stock prices. The 2008 global crisis that lies between periods of research became an interesting thing that shows the consistency of companies in Indonesia Stock Exchange (IDX) in distributing dividends because dividend is an important variable in this research.

Selected state-owned companies from five sectors namely mining; basic \& chemical industries; consumer goods; property, real estate, building \& construction; infrastructure, utilities \& transportation as samples for two reasons. First, there is the ownership structure variable that is proxied as government ownership. Second, state-owned companies have several advantages over private companies in technical performance (Top 20 stock all companies by trading value, trading frequency, and market capitalization) and fundamental performance (Top 20 stock all companies by net income and Top 10 stocks each sector by net income).

Lily et al. (2008) in his research entitled "Determinant of Dividend Payout in Thailand" to a company incorporated in SET100 listing on the Thailand Stock Exchange period 2001-2005. Liliy et al., (2008) examined the effect of 6 independent variables: Risk, Cash flow, Market to book value, Firm size, Ownership concentration and Financial leverage to Dividend Payout Ratio. The result of this research is Risk and Financial leverage variable have negative effect, while Cash flow variable, Market to book value, Firm size and Ownership concentration have no effect to Dividend Payout Ratio.

Kouki \& Guizani (2009) in his research entitled "Ownership Structure and Dividend Policy Evidence from the Tunisian Stock Market" on 29 companies consisting of 18 finance companies and 11 companies from the industrial sector listing on the Tunisian Stock Exchange. Kouki and Guizani (2009) examine the effects of Free Cash Flow (FCF), Leverage (Lev), Future growth opportunities (Q), Size, Institution Ownership (INST), State Ownership (ETA) and Ownership Con- tratration (MAJ) to Dividend Per Share . This study uses five models of regression equations, namely Model 1: DIV $=\mathrm{f}(\mathrm{FCF}$, Lev, Q, Size, INST, ETA, MAJ); Model 2: $\mathrm{DIV}=\mathrm{f}(\mathrm{FCF}, \mathrm{Lev}, \mathrm{Q}$, INST, ETA, MAJ); Model 3: DIV = f(FCF, Q, INST, ETA, MAJ); Model 4: DIV = $\mathrm{f}(\mathrm{FCF}$, Lev, Q, INST, MAJ); Model 5: DIV = f (FCF, Q, Size, INST). The result of this research is Free Cash Flow variable has positive effect on five models, Leverage variable has negative effect on model 4, variable $\mathrm{Q}$ has positive effect on all five models except on model 3 that is negative, Size variable has negative effect on model 1 and 5, Ownership has negative effect on the five models, State Ownership variable has negative effect on model 3, Ownership Concentration variable has positive effect on model 2, 3 and 4.

Chen \& Dhiensiri (2009) in his research entitled "Determinant of Dividend Policy: The Evidence from New Zealand" 
to 72 nonfinancial firms listed on the New Zealand Stock Exchange period 19911999. Chen and Dhiensiri (2009) examined the effect of 11 independent variables namely Cash Flow Variability, Dispersion Ownership, Insider Ownership, Free Cash Flow, Collateralisable Assets, Size, Beta, Sales Growth 1 for past, Sales Growth 2 for future, Stability and Imputation of Dividend Payout Ratio. The results of this study are Dispersion Ownership and Free Cash Flow variables have a positive influence, Insider Ownership and Sales Growth 1 for past have a negative influence, while other variables are Cash Flow Variablity, Collateralisable Assets, Size, Beta, Sales Growth 2 for future , Stability and Imputation has no effect on Dividend Payout Ratio.

Al-Kuwari (2009) examined the effect of Ownership Structure, Free Cash Flow, Firm Size, Growth Opportunities, Financial Leverage, Business Risk and Profitability to Dividend Payout Ratio. The result of this research are Ownership Structure, Firm Size, and Profitability have positive influence, Financial Leverage variable has negative effect, while Free Cash Flow, Business Risk and Growth Opportunities variables have no effect on Dividend Payout Ratio.

David (2010) in his research entitled "Analysis of Cash Position, Leverage, Growth, Liquidity to Dividend Payout Ratio on Companies Go Public in Busra Securities Indonesia" in 254 companies listing in Indonesia Stock Exchange period 20032005. David (2010) examines the effect of Cash Position, Debt to Equity Ratio, Growth, and Current Ratio to Dividend Payout Ratio. The result of this research is Cash position variable has positive influence in 2004, 2005, 2003-2005, Current ratio has positive influence in year 2003, while potential Growth variable and Debt to equity ratio have no effect to Dividend Payout Ratio.

Sharif, Salehi \& Bahadori (2010) in his research entitled "Ownership Structure of
Iranian Evidence and Payout Ratio" for a panel of Iran firms from 2002 and 2008. The result of this research there is a significant positive correlation between institutional ownership and payout ratio. The relation between payout ratio and individual ownership is negative. The most finding of the study indicates that Iranian companies with highly concentrated ownership distribute more dividends. There is a significantly positive correlation between the institutional ownership and the payout ratio. The relation between payout ratio and individual ownership is negative and the ownership concentration measured by the five largest shareholders affects positively on payout ratio.

Arif et al (2011) in his research entitled "Dividend Policy and Earnings Management: An Empirical Study of Pakistan Listed Companies" to 86 non-financial companies listed on the Karachi Stock Exchange for the 2004-2009 period. Arif et al., (2011) examined the effect of Discretionary Accrual, Return on Equity and Size on Dividend Payout Ratio. The result of this research is Size variable has negative effect, while Discretionary accrual and Return on equity variable have no effect to Dividend Payout Ratio.

Maladjian \& Khoury (2014) in his research entitled "Determinants of the Dividend Policy: An Empirical Study on the Lebanese Listed Banks" to 4 Banks listed on the Beirut Stock Exchange between the years of 2005-2011 found that the dividend payout policies are positively affected by the firm size, risk and previous year's dividends, but are negatively affected by the opportunity growth and profitability. The results obtained might indicate that firms pay dividends with the intention of reducing the agency conflicts.

Labhane \& Das (2015) in his research entitled "Determinants of Dividend Payout Ratio: Evidenve from Indian Companies" to 239 companies listed on the National Stock Exchange (NSE) periode 1994-1995 to 20122013 found that the market-to-book ratio, 
debt to equity ratio, free cash flow, business risk, age, size, profitability and dividend distribution tax variables are significant for the entire period of study. Whereas, the business risk, profitability and dividend distribution tax variables are significant for the entire period of study i.e. 1995-2013 as well as for the two sub-periods 19952003 and 2004-2013. Overall the results are consistent with the pecking order, transaction cost, signaling and firm life cycle theory of dividend policy.

King (2015) in his research entitled "Determinnats of Dividend Payout Ratios in Kenya". The sample are non-financial and non-utility listed on Nairobi Securities Exchange (NSE) from 2008-2012. It is observed that dividend payout ratio is impacted negatively by the growth rate, debt ratios and firm size and positively by earnings, market-to-book ratio and retained earnings to total assets ratio.

Echchabi \& Azouzi (2016) in his research entitled "Determinants of Dividend Payout Ratios In Tunusia: Insights In Light of The Jasmine Revolution" from the companies listed on the Tunisian Stock Exchange from 2003 through 2012. The findings indicated that net cash flow and market to book value have significant influence on the dividend payout, while the Jasmine revolution had no significant impact on the dividend payout among the Tunisian listed companies. The study extends the literature on the dividend policy towards a new context which is that of Tunisia.

Khan \& Ahmad (2017) in his research entitles "Determinants of Dividend Payout: An Empirical Study of Pharmaceutical Companies of Pakistan Stock Exchange (PSX)" data from 2009-2014 of listed pharmaceutical companies to determine the impact of selected variables on dividend payout. Findings reveal that audit type, liquidity, growth opportunities \& profitability are the key determinants of dividend payout of pharmaceutical companies of PSX. Other independent variables including taxation, risk, firm size and leverage insignificantly influence dividend payout decisions of pharmaceutical companies of PSX.

\section{Dividend payout ratio (DPR)}

Dividend payout ratio is used to measure dividend policy in this research. First, the consideration is the hypothesis in this study to take into account the relationship between the company's earnings are distributed as cash dividend and how much money is stored in the company's cash as retained earnings, thus reducing agency cost and for future investment. Secondly, dividend per share and dividend yield do not take into account cash dividend distribution in relation to how much money is kept in the company's cash. Dividend yields are used to measure corporate value and profitability for shareholders, and therefore are not necessarily related to agency costs (Lily et al., 2008; Kouki and Guizani, 2009; Chen \& Dhiensiri, 2009; Al-Kuwari, 2009; David, 2010; Sharif et al., 2010; Arif et al., 2011; Maladjian \& Khoury, 2014; Labhane \& Das, 2015; King, 2015; Echchabi \& Azouzi, 2016; Khan \& Ahmad, 2017).

\section{Ownership structure (GOV)}

Government ownership as an indicator to measure ownership structure, where the greater the ownership of the government the greater the ability of companies to distribute dividends with the aim of reducing agency cost. The reason is that companies that have high government ownership are not so difficult to finance investment projects, but the government as a strong investor must protect shareholders by paying high dividends because the government wants to build a good reputation in the stock exchange and do not want to have trouble with the 
holders shares related to the image of the company that is considered important in the capital market so that the ability to pay dividends is also getting bigger. This shows that the ownership structure has a positive effect on the dividend (Al-Kuwari, 2009).

$\mathrm{H}_{1}$ : Government ownership significantly positive to dividend payout ratio.

\section{Firm size (SIZE)}

Firm size is an important explanatory variable in which large firms pay dividends greater than small firms with the aim of reducing agency costs, therefore agency cost is related to firm size. Dividend payments can help monitor the performance of large companies indirectly because large dividend payments require large external financing so that managers can not make decisions freely or use profits for their own interests because of the control of the creditors. This shows that firm size has a positive effect on dividend (Lily et al., 2008; Kouki and Guizani, 2009; Chen \& Dhiensiri, 2009; Al-Kuwari, 2009; Sharif et al., 2010; Arif et al., 2011; Maladjian \& Khoury, 2014; Labhane \& Das, 2015).

$\mathrm{H}_{2}$ : Firm size significantly positive to dividend payout ratio.

\section{Growth opportunities (GROW)}

Sales growth as anindicator to measure growth opportunities, can be explained by 2 different things. First, a company with high growth or so-called growth firm concentrates on financial investment projects, focuses on expanding its business, using internal financing and has not been able to afford large debts because this kind of new company is growing and its age is still young, so the ability to pay a small dividend. This shows growth opportunities negatively affect the dividend. Second, companies with low growth or commonly called mature firm pay big dividends because big companies are big problem agencies so large dividend causes external financing needs of large companies, indirectly help monitor company performance because there is supervision from creditors and managers can not make decisions with freely, so that dividends can reduce agency costs. This shows that growth opprtunities have a positive effect on dividend (Chen \& Dhiensiri, 2009; Al-Kuwari, 2009; David, 2010; Sharif et al., 2010).

$\mathrm{H}_{3}$ : Sales growth significantly positive to dividend payout ratio.

\section{Financial leverage (LEV)}

Debt to equity ratio as an indicator to measure financial leverage, where the higher the financial leverage the higher the transaction cost because the company's debt is getting bigger and the company's ability to pay dividend is also getting weaker because the company avoids external financing. This shows that financial leverage has negative effect on dividend (Al-Kuwari, 2009; David, 2010; Maladjian \& Khoury, 2014; Labhane \& Das, 2015; Khan \& Ahmad, 2017).

\section{$\mathrm{H}_{4}$ : Debt to equity ratio significantly nega- tive to dividend payout ratio.}

\section{Profitability (PROF)}

Return on equity as an indicator to measure profitability, where the greater the net profit then produce Return on equity is higher, the higher Return on equity indicates the higher level of profitability also means the better and the company's ability to pay dividend is also getting bigger. This shows that profitability has a positive effect on dividend (Al-Kuwari, 2009; Arif et al., 2011; Maladjian \& Khoury, 2014; Khan \& Ahmad, 2017).

$\mathrm{H}_{5}$ : Return on equity significantly positive to dividend payout ratio. 


\section{Business risk (BETA)}

This study uses beta as a common proxy for firm business risk, which represents a firm's operating and financial risk. In addition, it has been argued that high-risk firms tend to have a higher volatility in their cash flows, than low-risk firms. Consequently, the external financing requirement of such firms will increase, driving them to reduce the dividend payout to avoid costly external financing. This shows that beta has negative effect on dividend (Chen \& Dhiensiri, 2009; Al-Kuwari, 2009).

$\mathrm{H}_{6}$ : Beta significantly negative to dividend payout ratio.

\section{Age (AGE)}

The life cycle variable age is used as a proxy for this study which is defined as the year from which the company has been into existence. Any firm has a well defined life cycle and is fundamental to the firm life cycle theory of dividend. The mature firms have less investment opportunities, more accumulated profit and retained earnings which cause them to pay more dividends. In contrast to this, younger firms are in the stage of new growth opportunities and need to build reserves of profit to finance their growth opportunities which result in less dividend payment. This shows that age has positive effect on dividend (Labhane \& Das, 2015).

$\mathrm{H}_{7}$ : Age significantly positive to dividend payout ratio.

\section{Previous year's dividends (PYD)}

In the real world, it is often believed that companies pay a steady stream of dividends because investors perceive firms with stable dividends as stronger and more valuable. The previous year's dividends positively affect the current dividend payout ratio of a company. In this study, the last year's dividends payout is used as a proxy variable for historical dividends. This shows that previous year's dividends has positive effect on dividend (Maladjian \& Khoury, 2014).

$\mathrm{H}_{8}$ : Previous year's dividends significantly positive to dividend payout ratio.

\section{Global crisis 2008 (CRISIS)}

In addition, a dummy variable has been added to illustrate the global crisis 2008. The latter is represented by (0) when there was not during the global crisis period of 2008 and (1) during the the global crisis period of 2008. This variable develop from research by Echchabi\& Azouzi (2016) that macro economics using the Jasmine revolution. This shows that global crisis 2008 has negative effect on dividend (Echchabi \& Azouzi, 2016).

$\mathrm{H}_{9}$ : Global crisis 2008 significantly negative to dividend payout ratio.

\section{METHOD}

This study used a purposive sampling technique is employed in selecting stateowned companies. To be included in the analysis, the companies must meet three criteria, which are (i) having regular annual report and account for the study period; (ii) showing positive earnings throughout the period of the study; (iii) paying continuous dividend payout throughout the period of the study. After the above filtering, only eight listed state-owned companies will be included in this study, which are PT Adhi Karya (Persero) Tbk, PT Aneka Tambang (Persero) Tbk, PT Kimia Farma (Persero) Tbk, PT Bukit Asam (Persero) Tbk, PT Perusahaan Gas Negara (Persero) Tbk, PT Semen Indonesia (Persero) Tbk, PT Timah (Persero) Tbk, and PT Telekomunikasi Indonesia (Persero) Tbk. 
Table 4. Variables with their symbols and expectations

\begin{tabular}{llc}
\hline \multicolumn{1}{c}{ Var } & \multicolumn{1}{c}{ Description } & Sign \\
\hline DPR & Cash Div/ Net profit & + \\
GOV & \% of government ownership & + \\
SIZE & Ln of total assets & + \\
GROW & Sales growth & + \\
LEV & Debt/ total assets & - \\
PROF & Net profit/ shareholder's equity & + \\
BETA & Rate of return on a given stock/ rate of return IHSG & - \\
AGE & Year of research - year of establishment of company & + \\
PYD & Previous Year's Dividend Payout & + \\
CRISIS & (0) when there was not during the global crisis period of 2008 & - \\
\hline
\end{tabular}

Compute by Author

$\mathrm{DPR}=\beta 0+\beta 1 \mathrm{GOV}+\beta 2 \mathrm{SIZE}+\beta 3 \mathrm{GROW}$

$+\beta 4 \mathrm{LEV}+\beta 5 \mathrm{PROF}+\beta 6 \mathrm{BETA}+\beta 7 \mathrm{AGE}$

$+\beta 8$ PYD $+\beta 9$ CRISIS $+\mathrm{e}$

All variables used in this study are defined in Table 4 along with the expected sign.

\section{RESULTS AND DISCUSSION}

This study based on multiple regression linier of state-owned enterprises companies listed in Indonesian Stock Exchange (IDX) period 2004-2013 with a total of 80 observations.

Here is the descriptive statistical results:

Table 5. Descriptive Statistics

\begin{tabular}{ccccc}
\hline Var & Min & Max & Mean & Std. Dev \\
\hline DPR & 10.87 & 152.17 & 44.49 & 18.71 \\
GOV & 51.00 & 90.03 & 61.99 & 12.28 \\
SIZE & 26.77 & 33.01 & 30.15 & 1.79 \\
GROW & -26.4 & 113.31 & 17.64 & 23.17 \\
LEV & 0.130 & 70.30 & 2.70 & 9.13 \\
PROF & 3.20 & 81.78 & 24.95 & 13.91 \\
BETA & -1.63 & 3.60 & 0.24 & 0.90 \\
AGE & 13.00 & 108.00 & 47.50 & 24.33 \\
PYD & 10.87 & 152.17 & 43.51 & 18.79 \\
CRISIS & 0.00 & 1.00 & 0.10 & 0.30 \\
\hline
\end{tabular}

Source: Compute by Author (Eviews 8)
Varibales dividend payout ratio and the previous year dividend payout ratio are equal maximum value there is $152.17 \%$ and the smallest are crisis 1 (dummy variable). Variables of government ownership and crisis present the largest means as compare with other variables, being $61.99 \%$ and 0.10 . Variables of age and grow present larger standard deviation as compared with other variables, being $24.33 \%$ and $23.17 \%$. The means of the dividend payout ratio and the previous year dividend payout ratio are similar, being $18.71 \%$ and $18.79 \%$, respectively.

Here are the results of the regression test:

Table 6. Regression Test Results

\begin{tabular}{cccc}
\hline Variables & Coef. & Prob & Decision \\
\hline GOV & -0.06 & 0.73 & Reject \\
SIZE & 5.01 & $0.00^{*}$ & Accept \\
GROW & 0.11 & 0.19 & Reject \\
LEV & 0.07 & 0.75 & Reject \\
PROF & -0.29 & 0.10 & Reject \\
BETA & -0.19 & 0.93 & Reject \\
AGE & 0.03 & 0.70 & Reject \\
PYD & 0.31 & $0.00^{*}$ & Accept \\
CRISIS & 13.24 & $0.05^{* *}$ & Accept \\
\hline
\end{tabular}

Source: Compute by Author (Eviews 8 )

*Significant level 5\%

**Significant level 10\% 
The first hypothesis results show that government ownership has coefficient -0.06 that is not support the research result which is done by Al-Kuwari (2009), the results also showed that government ownership no significantly to dividend payout ratio. The results of this study are in line with the research by Kouki \& Guizani (2009) that government ownership have no significantly to dividend payout ratio. Instead results shows that the ownership structure in developing countries like Indonesia does not affect the dividend payout ratio. It does not matter whether the percentage of shareholdings of government is large or small. In contrast to the findings of Al-Kuwari (2009) in the GCC country that ownership structure greatly affects the dividend payout ratio.

The second hyphotesis results show that firm size has coefficient 5.01 and significantly positive to dividend payout ratio. The results of this study are in line with the research by (Lily et al., 2008; Kouki and Guizani, 2009; Chen\& Dhiensiri, 2009; Al-Kuwari, 2009; Arif et al., 2011; Maladjian\& Khoury, 2014; Labhane\& Das, 2015). This shows that firm size in developing countries like Indonesia affects dividend payout ratio. Similar to AlKuwari (2009) findings in CGG countries that firm size greatly affects dividend payout ratio. The larger the firm size will be the greater the dividend payout ratio.

The third hypothesis results show that sales growth has coeffient 0.11 that is support research support which is done by L-Kuwari (2009) have a positive relationship and no significantly to dividend payout ratio. This shows that sales growth does not affect the dividend payout ratio. Similar to Al Kuwari (2009) findings in CGG country that sales growth does not affect dividend payout ratio. This means no matter whether the number of large or small sales growth was not an impact on the dividend payout ratio.

The fourth hypothesis results show that debt to equity ratio has coefficient 0.07 that is instead with the result research which is done by Al-Kuwari (2009) and no significantly to dividend payout ratio. The results of this study are in line with the research by David (2010). This shows that the debt to equity ratio does not affect the dividend payout ratio. Similar to David (2010) finding that debt to equity ratio does not affect the dividend payout ratio. This means no matter whether the small debt to equity ratio did not affect the dividend payout ratio.

The fifth hypothesis results show that return on equity has coefficient -0.29 that is instead with several study which is done by (Al-Kuwari, 2009; Arif et al., 2011; Maladjian\& Khoury, 2014; Khan\& Ahmad, 2017) and no significantly to dividend payout ratio. This shows that return on equity does not affect dividend payout ratio. Similar to Al-Kuwari (2009) findings that return on equity does not affect the dividend payout ratio. This means no matter whether the large return on equity turns out to have no impact on the dividend payout ratio.

The sixth hypothesis results show that beta has coefficient -0.19 that is support research by (Chen \& Dhiensiri, 2009; Al-Kuwari, 2009) and no significantly to dividend payout ratio. The results of this study are in line with the research by AlKuwari (2009). This shows that beta does not affect the dividend payout ratio. Similarly, Al-Kuwari (2009) finds that beta does not affect the dividend payout ratio. This does not matter whether the small beta did not affect the dividend payout ratio.

The seventh hypothesis results show that age has coefficient 0.03 which is support research result by Labhane \& Das (2015) and no significantly to dividend payout ratio. The results of this study are not support with the research by Labhane \& Das (2015). This shows that age does not affect the dividend payout ratio. Similar to Labhane \& Das (2015) findings that age does not affect the dividend payout ratio. This means no matter whether 
the age of the old or young companies did not affect the dividend payout ratio.

The eight hyphotesis results show that previous year's dividend payout significantly positive to dividend payout ratio with coefficient 0.31 . The results of this study are in line with the research by Maladjian \& Khoury (2014). This indicates that the previous year's dividend payout affects the dividend payout ratio. Similarly, Maladjian \& Khoury (2014) finds that the previous year's dividend payout affects the dividend payout ratio. This means that the previous year's dividend payout greatly affects the dividend payout ratio.

The last hyphotesis results show that global crisis 2008 significantly positive to dividend payout ratio. In addition, the 2008 global crisis greatly affected the dividend payout ratio with coefficient 13.24, support research result which is done by Echchabi \& Azouzi (2016).

\section{CONCLUSION}

From the above explanation it can be concluded that firm size, previous year's dividends, and global crisis 2008 significant to dividend payout ratio. The other variables there are ownership structure, growth opportunities, financial leverage, profitability, business risk, and age do not have significant to dividend payout ratio.

Limitations in this study there are, first, the object of research is only state-owned enterprises companies causing the number of companies observed only 8 companies, secondly, because the object of research is limited then the study period obtained is also limited only until 2013 because the company does not dividend divide starting 2014, third, the variables included do not include pecking order theory (market to book ratio), agency cost theory (free cash flow and tangibility of assets), and other variable control (current ratio and dividend tax)

Suggestions for next research is increasing the number of research samples and not restricting to state-owned enterprises companies, as an alternative ownership structure should not be proxyed as government ownership because this is very restrictive number of observation samples, the study period to 2016, and to add a market to book ratio, free cash flow, tangibility assets, current ratio and dividend tax (AlKuwari, 2009; Labhane\& Das, 2015).

\section{REFERENCES}

Al-Kuwari, Duha. 2009. Determinants of the Dividend Policy in Emerging Stock Exchange: The Case of GCC Countries. Global Economy and Finance Journal Vol. 2 No. 2, 38-63.

Arif, Ahmed, Afsheen Abrar, Mehwish Aziz Khan, Ferheen Kayani and Syed Zulfiqar Ali Shah. 2011. Dividend Policy and Earnings Management: An Empirical Study of Pakistani Listed Companies. Information Management and Business Review Vol.3 No.2, 68-77.

Black, F. 1976. The Dividend Puzzle, The Journal of Portfolio Management, Winter, Vol. 2(2), 5-8

Bodie Zvi., Alex Kane., Alan J. Marcus and Ravi Jain. 2014. Investments, $9^{\text {th }}$ edition. Singapore: Mc Graw Hill Education.

Chen, Jianguo and Nont Dhiensiri. 2009. Determinants of Dividend Policy: The Evidence from New Zealand. International Research Journal of Finance and Economics - Issue 34, 18-28.

David. 2010. Analisis Cash Position, Leverage, Growth, Liquidity 
Terhadap Dividend Payout Ratio Pada Perusahaan-Perusahaan yang go public di Bursa Efek Indonesia. Telaah Manajemen. Vol. 5 No.1, 1-16.

Echchabi, A and Azouzi, D. 2016. Determinants of Dividend Payout Ratios In Tunusia: Insights In Light of The Jasmine Revolution Journal of Accounting, Finance and Auditing Studies. Vol 2 No 1 Pg 1-13

Gitman, Lawrence J and Chad J. Zutter. 2015. Principles of Managerial Finance, 14th edition. USA: Pearson.

Khan, F, A and Ahmad, N. 2017. Determinnats of Dividend Payout: An Empirical Study of Pharmaceutical Companies of Pakistan Stock Exchange (PSX). Journal of Financial Studies \& Research. Vol 2017, Article ID 538214, Pg.1-16.

King, R. 2015. Determinants of Dividend Payout Ratios in Kenya. Research Journal of Finance and Accounting. Vol 6 No 1 Pg. 48-52.

Kouki, Mondher and Moncef Guizani. 2009. Ownership Structure and Dividend Policy Evidence from the Tunisian Stock Market. European Journal of Scientific Research. Vol. 25 No.1, 4253.

Labhane, N. B and Das, R. C. 2015. Determinants of Dividend Payout Ratio: Evidence from Indian Companies. Business and Economic Research. Vol 5, No. 2 Pg 217-241.
Lily, Jaratin, Sundar Venkatesh and Thumwimon Sukesrm. 2008. Determinants of Dividend Payout in Thailand. UBU Journal Vol 11 No.3, 73-81.

Lintner, J. 1962. Dividends, Earnings, Leverage, Stock Prices, and the Supplay of Capital to Corporations. Review of Economics and Statistics 44, pp. 243-269.

Lintner, J., 1956, Distribution of Incomes of Corporations Among Dividends, Retained Earnings, and Taxes. American Economic Review. 46, 97113.

Maladjian, C and Khoury, R. E. 2014. Determinants of the Dividned Policy: An Empirical Study on the Lebanese Listed Banks. International Journal of Economics and Finance, Vol 6, No. 4 Pg. 240-256.

Miller, M. and D. Modigliani, 1961, Dividend Policy, Growth, and the Valuation of Shares. Journal of Business 34, 411433.

Satriani, Wahyu. 2014. Investasi ORI 11 lebih menarik dari deposito? http://investasi.kontan.co.id/news/ investasi-ori-11-lebih-menarik-darideposito

Sharid, S, J, S., Salehi, M., \& Bahadori, H. 2010. Ownership Structure of Iranian Evidence and Payout Ratio. Asian Social Science. Vol. 6, No. 7 Pag. 3642. 